\title{
Spiritual and moral values: an anthropological study of the duty and desire categories
}

\author{
Elena A. Shtekhman ${ }^{1 *}$, Yuliya A. Melnik ${ }^{2}$, Alina V. Biyakaeva², Anna V. Baskakova ${ }^{2}$, and \\ Olga $V$. Shkurko ${ }^{3}$ \\ ${ }^{1}$ Russian State Academy of Intellectual Property, Department of General Education, Moscow, Russia \\ ${ }^{2}$ The Military University of the Ministry of Defense of the Russian Federation, Department of \\ Russian Philology, Moscow, Russia \\ ${ }^{3}$ Omsk Tank-Automotive Engineering Institute, Department of Russian Philology, Omsk, Russia
}

\begin{abstract}
The article is devoted to the study of phenomena, such as duty and desire. These phenomena are interpreted in different ways within the framework of various philosophical trends, starting from antiquity and ending with modernity. The authors emphasize the lack of consensus in the philosophical and scientific community in the interpretation of these categories. Thus, R. Descartes believed that the phenomenon of debt arose in the human mind under the influence of social conditions. On the contrary, I. Kant and C. Cordner argued that duty was a priori concept not associated with practice and life. In turn, L.Yu. Nikolaeva understood duty as the basis for forming the national-cultural ideal. Plato explained the phenomenon of desire by the imperfection of a human, whereas Aristotle understood desire as the product of a pleasant sensation. In turn, Spinoza argued that desire was an individual form of cognition of the world. Descartes and J. Locke believed that desire was a need for something that was not currently available. In general, the categories of duty and desire were clearly distinguished. Most philosophers consider duty as a characteristic of the social being of the individual, whereas desire is considered to be an empirical category, i.e., generated by the sensory experience of the individual. However, it is necessary not only to study these concepts more deeply but also to reveal their role in forming spiritual and moral values.

Keywords: consciousness, ethics, philosophy, category.
\end{abstract}

\section{Introduction}

For centuries, philosophers have been drawn to categories, such as duty and desire. What is their essence? What is the relationship between duty and desire? Are we consciously following our duty? Where are the origins of desire?

Even though the phenomena under consideration have been in the focus of attention of philosophers since ancient times, the problem still remains relevant and insufficiently studied. The purpose of the present research is to analyze spiritual and moral values associated with the categories of duty and desire. The purpose of the work identified the following tasks:

\footnotetext{
*Corresponding author: shte-elena@yandex.ru
} 
- to interpret the phenomena of duty and desire in terms of spiritual and moral values;

- to study the theoretical basis of the issue under study;

- to describe approaches to understanding the essence of the phenomena under consideration.

\section{Methods}

The study was based on the dialectical method since through this method it was possible to consider the phenomena of duty and desire in terms of their influence on the formation of spiritual and moral values. The structure and content of the described phenomena were revealed using the analysis, synthesis, induction, and deduction methods.

\section{Results}

The authors have come to the conclusion that desire is the passion of longing, which is not a moral action, since it is unreasonable, and therefore not free, while duty is the need to perform certain duties, to obey someone, forgetting about their desires. A moral duty is a duty only if it is performed voluntarily, contrary to the desires and needs.

\section{Discussion}

Descartes [1], Kant [2], and J. Fichte consider duty as a category of ethics. "Metaphysical reflections" by Descartes are devoted, among other things, to the reflection that there is a certain force that strives to mislead a person. The genesis of the subject's consciousness is related to the development of the phenomenon of the very debt, while the change in its content and understanding is associated not only with external social factors but also with the transformation of consciousness. The phenomenon of debt arises in one's consciousness under the influence of social conditions and reflects the entire range of conditions of human existence. Consequently, the consciousness and awareness of duty are a characteristic of the social existence of the individual. Kant defined the modality of duty as an absolute category. In his opinion, this category is justified by practical reason. The reason and goodwill of a human are the starting point of human moral duty.

Developing the ideas of Kant, Fichte used to note that a person perceived the external world as independent of his will; this was a necessity. "Where did the system of ideas accompanied by a sense of necessity come from?" - asks Fichte, and replies that their source is "the action of the intellect", rather than Kant's "thing-in-itself". According to Fichte, the ego does not depend on desires but on duty, moral necessity, and through this it is free.

Contemporary Russian researchers follow the Kantian tradition of interpreting duty and speak about the role of the latter in the formation of spiritual and moral values. Thus, Nikolaeva [3] represents duty (on a par with freedom and good) as a basis for the children's upbringing methodology. Yu.A. Panasenko and V.S. Elagina [4] talk about the duty as a professionally-oriented moral value of a Russian officer, while A.A. Stoppel [5] considers duty as the spiritual and moral value, most significant for any military specialist, which is important both professionally, socially, and morally.

While the category of duty is sufficiently widely represented in the works of philosophers, the category of desire is still not clearly defined. Desire is the motive for most of the actions of the subject, and it seems essential for philosophers since the presence of desire allows changing being.

Aristotle defined a human as a perfect animal having passions and needs. Thomas Aquinas believed that the ability to desire was in the passive part of the human soul. 
Descartes, in his philosophical works, defines "the passion of desire" as "the excitement of the soul caused by spirits that set the soul to desire in the future what seems appropriate to it. They want not only the good that does not exist at the moment, but also the preservation of what is available. The object of desire can be also the absence of evil, both which already exists and which is possible in the future" [1:518].

The attitude of Locke correlates with the standpoint of Descartes: "The anxiety experienced by a person in the absence of a thing, whose possession causes the idea of pleasure, we call desire ... <.. > In fact, whatever good is supposed to be, if its absence does not cause trouble and suffering, if a person feels calm and content without it, then there is no desire for this good, no desire to acquire it..." [7:282].

In the 20th century, J. Lacan and J.-P. Sartre developed the idea of the relationship between absence and desire [8: 455]. Lacan defines the function of desire as "need to be".

Another direction of philosophical thought, represented in the works of B. Spinoza, F. Nietzsche, G. Deleuze, F. Guattari, defines desire as motivation [9].

So, the category of desire in philosophy is understood as 1) the absence of something or 2) a certain form of knowledge of the world.

In this sense, the category of desire is also used by contemporary Russian scientists when analyzing various problems: in the context of students' value orientations - in works of N.V. Stepanova and V.V. Nevolina [10], as the basis for forming the quality of life potential - in studies of N.V. Kamalova [11], as the cognitive basis for the category of optativity of natural language - in articles of E.V. Altabaeva [12], etc.

Besides, contemporary philosophers consider the phenomena of duty and desire within the scope of ethics [13-18]. Some contemporary authors consider debt as a social phenomenon [19], as the basis for forming the national-cultural ideal [3], and as a professionally-oriented moral value $[4,5]$.

To understand the philosophical foundations of the spiritual and moral values formation, it is necessary to focus on the issue of understanding the categories of desire and wish (want to) in the Russian language consciousness. In the definition of these lexemes, explanatory dictionaries agree that desire and wish denote the same concepts.

Wish is characterized by the fact that it encourages a person to experience something in reality. From this viewpoint, the individual decides what should be given up for the wish be implemented. Lexeme of desire, as a rule, is accompanied by the infinitive in the function definition: a desire to travel, desire to learn, desire to sleep, desire to think, desire to say, desire to test, desire to get, desire to help, etc. This fact proves that the infinitive indicates a feature, concretizes the desire.

Desire from the viewpoint of language is an internal drive, striving to implement something, to possess something, while wish is a desire that can go through all stages of development [20].

Not only any actions and feelings but various realities of the world around can be the object of desire and wish. For example: to go to see the championship for a fan is a desire; Do you have a desire to do physical education and sports?

The desire for something, unlike wish, can be directed to the addressee, if it is focused on feelings, emotions. To compare: My desire is you to have love/ I wish you to love. One can share the desire, but it is impossible to share the wish. The wish is hidden and becomes apparent only when it is fulfilled: I wish to be alone; I wish to be with Oleg; I wish to write a book. Desire, on the contrary, is open-hearted. Desire and wish can be described as states that people experience. For example, I wish to achieve everything in life by myself; I desire... this ... to enter a bulldozer training course.

Thus, the desire can be directed to the addressee. It can take over the person, it can be suppressed, made up, one can have it. Wish is individualistic, it has stages of development. Nevertheless, both desire and wish are impetus to achieve something. 


\section{Conclusion}

When analyzing the categories of duty and desire, the authors have concluded that there is still a need for further anthropological research of the duty and desire categories, since they play an important role in forming spiritual and moral values of the individual and the country in general.

The prospects of further research consist in the analysis of the categories of duty and desire as the basis for forming moral and spiritual values and upbringing.

\section{References}

1. R. Descartes, Sochineniya v 2 tomakh [Works in 2 volumes], 1, 518 (Mysl, Moscow, 1989)

2. I. Kant, Sochineniya v 6 tomakh [Works in six volumes], 4(1), 544 (Mysl, Moscow, 1965)

3. L.Yu. Nikolaeva, Naukovedeniye, 7(1) (2015). Accessed on: September 6, 2020. [Online]. Available: http://naukovedenie.ru/PDF/21PVN115

4. Yu.A. Panasenko, V.S. Elagina, Gumanizatsiya Obrazovaniya, 3, 138-143 (2015)

5. A.A. Shtoppel, Bulletin of the Moscow State Region University, Series Philosophical Sciences, 2, 48-53 (2015)

6. A.V. Petrovsky (Ed.), Obshchaya psikhologiya [General psychology] (Prosveshcheniye, Moscow, 1987)

7. J. Locke, Sochineniya v 3 tomakh. Tom 1. Opyt o chelovecheskom razumenii. Filosofskoye naslediye [Works in 3 volumes. Vol. 1. An essay concerning human understanding. Philosophical heritage], 282 (Mysl, Moscow, 1985)

8. J.P. Sartre, Bytiye i nichto: opyt fenomenologicheskoy ontologii [Being and nothingness: an essay on phenomenological ontology], 455 (Republic, Moscow, 2000)

9. B. Spinoza, Izbrannyie proizvedeniya. Tom 1 [Selected Works. Vol. 1] (Izdatelstvo politicheskoy literatury, Moscow, 1957)

10. N.V. Stepanova, V.V. Nevolina, Mir Nauki, Kultury I Obrazovaniya, 6(49), 239-241 (2014)

11. N.V. Kamalova, Fundamental'nyye I Prikladnyye Issledovaniya: Problemy i Rezul'taty, 3, 84-88 (2013)

12. E.V. Altabaeva, Issues of Cognitive Linguistics, 4, 109-118 (2007)

13. A.V. Darmogray, Scientific Electronic Journal Meridian, 6(40), 348-350 (2020)

14. C. Cordner, Duty and Ethical Motivation, in Ethical Encounter. Swansea Studies in Philosophy (Palgrave Macmillan, London, 2002). https://doi.org/10.1057/9780230509177_6

15. R.M. Robinson, Kant's Categorical Imperative and Moral Duties: The Ethical Norm of Managerial Decisions, in Imperfect Duties of Management, 11-38 (Palgrave Macmillan, Cham, 2019). https://doi.org/10.1007/978-3-319-99792-6_2

16. P. Ellis, Journal of Kidney Care, 5(1), 30-32 (2020). https://doi.org/10.12968/jokc.2020.5.1.30

17. I. Vorsatz, Ágora Estudos em Teoria Psicanalítica, 21(2), 215-223 (2018). https://doi.org/10.1590/S1516-14982018002007 
18. A. Bagnulo, Desire, Conflict, and Tradition in Ethics in the Conflicts of Modernity. Project: Contemporary Political Thought. Expositions, 14(1), 86-96 (2020)

19. T.B. Sergeeva, Dolg kak sotsial'nyy fenomen [Debt as a social phenomenon], in Proceedings of the international conference "Tendentsii razvitiya vysshego obrazovaniya $\mathrm{v}$ sovremennom mire [Trends in the development of higher education in the modern world]", 12 September 2019, Sochi, Russia, 52-57 (2019)

20. J.E. de Castro, Fractal: Revista de Psicologia, 32(1), 12-20 (2020). https://doi.org/10.22409/1984-0292/v32i1/5628 